$\begin{array}{ll}\text { NAMA } & \text { : Dean Syahputra Utama } \\ \text { STAMBUK } & \text { : C1D5 } 16016 \\ \text { JURUSAN } & : \text { Ilmu Komunikasi Konsentrasi Hubungan Internasional } \\ \text { FAKULTAS } & : \text { Ilmu Sosial dan Ilmu Politik } \\ \text { UNIVERSITAS } & \text { : Halu Oleo }\end{array}$

\title{
TUGAS REVIEW JURNAL
}

\section{Tinjauan Implementasi Pembangunan Berkelanjutan: Pengelolaan Sampah Kota Kendari}

Jurnal ini membahas mengenai masalah isu pengolahan sampah yang menjadi perhatian Pemerintah Daerah Kota Kendari. Dimana sampah ini masih menjadi suatu permasalahan bagi masyarakat sehingga Pemerintah Daerah Kota Kendari membuat sebuah kebijakan yang mengatur tentang pengolahan sampah dalam Peraturan Daerah Kota Kendari Nomor 4 Tahun 2015. Hal ini menjadi tantangan tersendiri bagi Pemerintah Daerah Kota Kendari yang berbasis sustainable development di Kota Kendari yang menjadi salah satu tujuan pembangunan berkelanjutan dalam agenda 2030 dalam mengurangi dampak lingkungan perkotaan dengan presentase sampah perkotaan yang tertangani.

Jurnal penelitian ini bertujuan untuk mengetahui implementasi kebijakan pengolahan sampah dengan menggunakan konsep implementasi kebijakan oleh Edward III dan mengaitkan dengan konsep pembangunan berkelanjutan dan agenda 2030 Tujuan Pembangunan Berkelanjutan (SDGs). 
Metode yang digunakan dalam jurnal penelitian ini adalah menggunakan penelitian deskripstif dengan pendekatan kualitatif. Sedangkan sumber data yang digunakan adalah dengan menggunakan data primer dan data sekunder dengan menggunakan teknik pengumpulan data wawancara mendalam dan dokumentasi. Jurnal penelitian ini menggunakan metode analisis model interaktif yang terdiri dari cara pengumpulan data, reduksi data, penyajian data, dan simpulan. menurut Miles \& Huberman (2007).

Hasil dari jurnal penelitian ini dikatakan pengolahan sampah di Kota Kendari yang diatur oleh Pasal 19 Peraturan Daerah No 4 Tahun 2015 bahwa penanganan sampah rumah tangga dan sejenis sampah rumah tangga meilputi pemilahan, pengumpulan, pengangkuran, pengolahan, dan pemrosesan akhir sampah. Dalam tantangan Implementasi Kebijakan pengolahan Sampah di Kota Kendari dipengaruhi oleh beberapa aspek yakni Komunikasi, Sumberdaya, disposisi, dan struktur birokrasi. Dari beberapa pengaruh dari keempat aspek tersebut telah memperhatikan aspek - aspek sustainable development yaitu perhatian ekonomi, sosial dan lingkungan. Pengolahan sampah di Kota Kendari juga secara langsung sudah berkontribusi pada upaya pencapaian Tujuan Pembangunan Berkelanjutan/Suistainable Development Goals (SDGs) 2020 dimana DLHK Kota Kendari telah manangani sampah perkotaan 73.30 persen dari 247.96 per ton timbunan sampah di Kota Kendari.

Hal yang bisa dikembangkan dalam studi ini ialah, sebaiknya penulis juga mencantumkan terkait kendala apa saja yang dihadapi oleh pemerintah dalam pengimplementasian pembangunan berkelanjutan dalam pengolahan sampah di Kendari. Selain itu, penelitian ini juga dapat dikembangkan lebih lanjut dalam SDGs tujuan ke-14 dalam terget ke-1, dimana di dalam tujuan ini membahas mengenai perlindungan keberlanjutan ekosistem laut, mengingat sampah di laut Kota Kendari juga masih memprihatinkan. Sehingga, Dalam tujuan ini juga bisa dilakukannya pengolahan sampah yang berada di laut Kota Kendari. Selain SDGs 
tujuan ke-14, jurnal penelitian ini juga dapat di kembangkan dalam SDGs tujuan ke-12 indikator ke-5 yang membahas mengenai "pada tahun 2030, secara substansial mengurangi produksi limbah melalui tindakan pencegahan, pengurangan, daur ulang dan penggunaan kembali.

\section{Peluang dan Tantangan Pengembangan Industri Kreatif Kuliner dalam Pencapaian SDGs}

Jurnal penelitian ini membahas mengenai masalah dalam tantangan pemngembangan industri kreatif kuliner. Seperti yang kita ketahui sektor ekonomi kreatif subsektor kuliner belum dikembangkan secara optimal, padahal Industri kreatif ini merupakan industri yang berpotensi untuk dikembangkan di Kota Kendari mengingat kuliner sebagai salah satu kebutuhan dasar dari manusia.

Tujuan jurnal penelitian ini membahas mengenai peluang dan tantangan pengembangan industri kreatif kuliner di Kota Kendari serta kontribusinya dalam upaya pencapaian SDGs.

Metode yang digunakan dalam jurnal penelitian ini adalah dengan menggunakan deksriptif kualitatif untuk menganalisis kondisi pendukung dan penghambat sebagai peluang dan tantangan pengembangan industri kratif kuliner di Kota Kendari. Penulis juga menggunakan teknik pengumpulan data dengan menggunakan metode wawancara dan dokumentasi dengan teknik analisa data model interaktif yang terdiri dari cara pengumpulan data, reduksi data, penyajian data, dan simpulan. menurut Miles, Huberman \& Saldana (2014).

Hasil dari jurnal penelitian ini menunjukan bahwa peluang pengembangan industri kreatif kuliner dipicu oleh tumbuhnya minat kewirausahaan dan kreatifitas pelaku industri kreatif kuliner, hal ini mendapatkan momentumnya karena didorong oleh tren kuliner sebagai lifestyle and leisure, 
serta dukungan program pemerintah dalam pengembangan kuliner itu sendiri. Adapun tantangan yang dihadapi seperti modal usaha, perizinan, dan tempat/ruang usaha untuk pengembangan industri kreatif kuliner. Namun, secara keseluruhan keberadaan industri kreatif kuliner di Kota Kendari ternyata mampu untuk mendukung pencapaian SGDs 2030 pada tujuan ke 8 untuk penciptaan lapangan pekerjaan serta menyerap tenaga kerja usia muda.

Hal yang bisa dikembangkan dalam studi ini ialah, peneliti juga dapat mengembangkannya dalam SDGs tujuan ke-9 (Infrastruktur, Industri, dan Inovasi) dalam tujuan ke-2 yang membahas dalam mendorong industrialisasi yang inklusif dan berkelanjutan dan, pada tahun 2030, secara signifikan meningkatkan bagian industri terhadap penciptaan lapangan kerja dan produk domestik bruto, sejalan dengan situasi nasional, dan menggandakan bagian industri di negara kurang berkembang). Sehingga, dalam pengembangan industri kuliner kreatif di Kota Kendari bisa di kembangkan secara signifikan dalam penciptaan lapangan pekerjaan dan lainnya. Selain penggunaan pendekatan SDGs

diatas. Penulis juga dapat mengembangkan terkait apa saja peran pemerintah dalam membangun industri kuliner kreatif ini, apakah pemerintah membantu dalam hal seperti kemudahan perizinan ataukah dalam hal lainnya.

\section{Refrensi:}

Sudirman, F.A., Phradiansah. (2019). Tinjauan Implementasi Pembangunan Berkelanjutan: Pengolaan Sampah Kota Kendari. Jurnal Sosial Politik, 5 (2), 291-305. https://doi.org/10.22219/sospol.v5i2.9821

Sudirman, F., Susilawaty, F., \& Adam, A. (2020). Peluang dan Tantangan Pengembangan Industri Kreatif Kuliner dalam Pencapaian SDGs. Societas : Jurnal Ilmu Administrasi dan Sosial, 9 (1), 12-24. https://doi.org/10.35724/sjias.v9i1.2804 